\title{
Assessing spatial and temporal patchiness of the autotrophic ciliate Myrionecta rubra: a case study in a coastal lagoon
}

\author{
Celia Bulit ${ }^{1, *}$, Carlos Díaz-Ávalos ${ }^{2}$, David J. S. Montagnes ${ }^{3}$ \\ ${ }^{1}$ Departamento El Hombre y su Ambiente, Universidad Autónoma Metropolitana-Xochimilco, Calzada del Hueso 1100, \\ 04960 México DF, Mexico \\ ${ }^{2}$ Instituto de Investigaciones en Matemáticas Aplicadas y en Sistemas, Universidad Nacional Autónoma de México, Apartado \\ Postal 20-726, 01000 México DF, Mexico \\ ${ }^{3}$ School of Biological Sciences, University of Liverpool, Biosciences Building, Crown Street, Liverpool L69 7ZB, UK
}

\begin{abstract}
Myrionecta rubra patchiness in a Mexican coastal lagoon was studied. The 3 objectives were to (1) characterize the spatial distribution of $M$. rubra patches through time; (2) characterize and model the spatial distribution of $M$. rubra at scales ranging from $\mathrm{m}$ to $\mathrm{km}$, and from $1 \mathrm{wk}$ to more than $1 \mathrm{yr}$; and (3) to place the patchiness patterns of M. rubra into an ecological context. Geostatistical analysis was applied to data collected from simple and nested sampling grids in different seasons; autocorrelation analysis was used to detect temporal regularities over $55 \mathrm{wk}$. Classical statistics were applied to data from 10 sites in the lagoon to identify trends relating ciliate abundance to environmental conditions. Patches were detected and characterized using empirical variograms and modelled by omnidirectional Gaussian and exponential functions. For most of the analysis variance was low in the nugget parameter, indicating a strong spatial resolution of the data, and the range parameter indicated that $M$. rubra formed patches of 10, 20, 80, 130, and $170 \mathrm{~m}$. Spatial analysis using hierarchical grids produced a more detailed assessment of patches than single grids alone. Conditional simulation of patches indicated the presence of a $>2 \mathrm{~km}$ patch covering most of the western lagoon. Patch densities varied from between 4 and 700 cells ml-1 . M. rubra abundance exhibited a temporal, pulse-like pattern; autocorrelation revealed a $13 \mathrm{wk}$ periodicity. At the lagoonal level, multiple regression revealed a trend towards higher abundance in the north-west of the lagoon and a decrease during the dry season. Finally, we speculate on the forces causing heterogeneity at large $(>1000 \mathrm{~m})$, meso (100 to $1000 \mathrm{~m})$, and fine ( 1 to $100 \mathrm{~m}$ ) scales by examining physical-chemical environmental factors and physiological behavioural properties of the ciliate and its potential predators. We propose that $M$. rubra patches originate by fragmentation of larger patches, growth of smaller patches, and physical-behavioural aggregation of cells.
\end{abstract}

KEY WORDS: Geostatistics - Conditional simulation - Mesodinium rubrum - Mexico · Ordinary kriging $\cdot$ Variographic analysis

\section{INTRODUCTION}

Spatial patchiness is an inherent property of aquatic ecosystems. Although Myrionecta rubra (=Mesodinium rubrum) is a productive autotrophic protist and shows remarkable horizontal patchiness, occurring in thin layers and large blooms (Crawford 1989, Lind- holm \& Mörk 1990), little quantitative information exists on the structure of its spatial distribution. Likewise, there are no quantitative data on the patchiness and seasonal distribution of M. rubra in tropical coastal lagoons, although it is abundant in these ecosystems.

The ecological success of Myrionecta rubra is probably due to a combination of its locomotory behaviour 
and its autotrophic capacities (Stoecker et al. 1989). This ciliate can be a dominant member of the autotrophic plankton under non-bloom conditions. Its ability to accumulate near the sea surface and to photosynthesize at near maximum rates at high light intensities can give it an advantage over other planktonic autotrophs (Stoecker et al. 1991). In addition, its rapid swimming behaviour appears to reduce its susceptibility to grazing (Jonsson \& Tiselius 1990), and finally, M. rubra is able to migrate, responding to turbulence. Thus, it might be expected that this cosmopolitan species forms distinct patches at different scales.

From an early review (Haury et al. 1978) and subsequent work over the years (e.g. Fasham 1978, Harris 1980, Platt \& Denman 1980, Denman \& Powell 1984, Mackas et al. 1985, Steele \& Henderson 1992, Powell \& Okubo 1994, Franks \& Walstad 1997, Lennert-Cody \& Franks 2002), considerable effort has been dedicated towards examining the mechanisms that generate patches at different scales. More recent work (e.g. Legendre 1993, Legendre \& Legendre 1998) has detailed, examined, and applied spatial statistical methods to the study of patchiness.

In this work, we studied the spatio-temporal variation of Myrionecta rubra over an annual cycle, from small $(\mathrm{m})$ to large $(\mathrm{km})$ scale in a lagoon on the Pacific coast of Mexico; to do this we used traditional and geostatistical techniques. Traditional techniques indicate the trends relating ciliate abundance to environmental conditions (Neter et al. 1990), while geostatistical tools provide insight into the qualitative and quantitative characterization of the spatial variation of planktonic populations (Bulit et al. 2003, C. Díaz-Ávalos, C. Bulit \& D. J. S. Montagnes unpubl.). This paper has 3 objectives: (1) to characterize the spatial distribution of M. rubra patches through time; (2) to characterize and model the spatial distribution of $M$. rubra at scales ranging from $\mathrm{m}$ to $\mathrm{km}$ and from $1 \mathrm{wk}$ to $>1 \mathrm{yr}$; and (3) to place the temporal and spatial patterns of patchiness of $M$. rubra into an ecological context.

\section{MATERIALS AND METHODS}

Study area. Chautengo is a barred, inner-shelf lagoon (Lankford 1977) located on the Mexican Pacific coast (Fig. 1). Following the criteria of Kjerfve (1994), Chautengo is a choked lagoon, characterized by dominant wind forcing, with intermittent stratification events, and phytoplankton as the dominant autotrophs
(Knoppers 1994). At the southern margin, a sand bar has a small (100 to $200 \mathrm{~m}$ ) opening to the sea during part or all of the rainy season (late May to November) and is closed during the dry season.

The lagoon has a surface of $36 \mathrm{~km}^{2}$, a depth of 0.5 to $2.5 \mathrm{~m}$, and seasonal river inputs (Mee 1978). The water volume increases from June onwards, when water discharge surpasses evaporation (Mandelli \& VázquezBotello 1976). Salinity changes during the openingclosing annual cycle: following the bar closure, salinity increases due to evaporation; salinity then decreases during the rainy season, and the lagoon is refilled; then, when the bar opens to the sea, water is discharged, and tidal exchange increases salinity. Thus, salinity ranges from 0 to 33.5 psu during the year, and there is strong haline stratification in some areas, in spite of the shallowness of the lagoon (Mee 1977).

The climate for the region is warm, sub-humid with summer rainfall and an average annual temperature above $26^{\circ} \mathrm{C}$ (García 1973). During the rainy season (late May to November), SE winds prevail; NE winds prevail during the dry season. Probably more significant to the formation of plankton patches are the thermal sea breezes, which have velocities that may exceed $5 \mathrm{~m} \mathrm{~s}^{-1}$ and occur typically in the mid-afternoon each day (Mee 1978).

Sampling and enumeration. Unless otherwise stated, sampling was conducted by deploying a $400 \mathrm{ml}$ Niskin-type bottle, built for use in shallow waters, at $0.4 \mathrm{~m}$. Samples taken from the $400 \mathrm{ml}$ bottle were homogenized, and for each, a $100 \mathrm{ml}$ subsample was

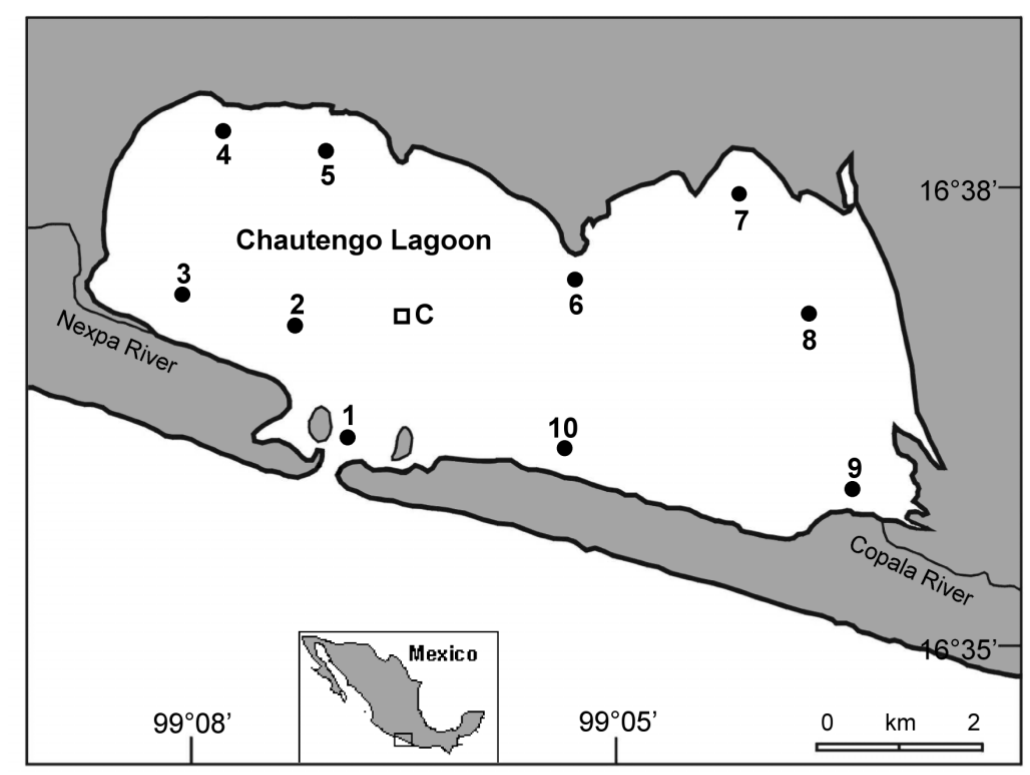

Fig. 1. Chautengo lagoon, Mexico, indicating the location of the one grid site (C) where geostatistical analyses were conducted and long-term data were collected, and the 10 sites $(\bullet)$ where 5 seasonal samplings took place. The box on the inset of Mexico indicates the lagoon location 
preserved with acid Lugol's iodine (2\% final concentration). Myrionecta rubra was enumerated at $200 \times$ and $400 \times$ magnifications in a $5 \mathrm{ml}$ Utermöhl chamber; this usually corresponded to counting 50 to 500 cells. Unless otherwise stated, at the same time that $M$. rubra samples were taken, water temperature, salinity, and transparency were determined with a thermometer, a refractometer, and a Secchi disk, respectively.

Distribution and seasonal cycle of Myrionecta rubra. Ten sites, representing the lagoon, were sampled in October 2000, January, March, May and August 2001 (Fig. 1). Vertical surveys were conducted in October, January, March, and May at Site C (Fig. 1). These profiles were obtained by deploying a rack of 4 horizontally oriented $(400 \mathrm{ml})$ bottles, sampling at 0.2 , $0.4,0.6$ and $0.8 \mathrm{~m}$ in October, and at $0.3,0.4,0.6$ and 0.9 in January, March, and May, at $\sim 12: 00 \mathrm{~h}$, before the water column was mixed by the thermal winds; temperature and salinity profiles were also recorded. To assess seasonal variability, 55 samples were taken at $\sim 0.4 \mathrm{~m}$ at Site C (Fig. 1) weekly, from November 1, 2000 to December 6, 2001.

Temporal changes of patchiness. Myrionecta rubra abundance was determined on 5 occasions (October 2000; January, March, May and September 2001) at sampling points of a grid located near the center of the lagoon (16 37.4' N, 99 06.6' W, Site C, Fig. 1). In October 2000 , the grid was $40 \times 40 \mathrm{~m}^{2}$, divided at $10 \mathrm{~m}$ intervals, and 5 additional sampling points were included $1 \mathrm{~m}$ from some of the points, to provide information on small-scale variation; thus, 30 samples were taken. In January, March, May, and September 2001, sampling grids of $40 \times 40 \mathrm{~m}^{2}$ were sampled at $10 \mathrm{~m}$ intervals, and in January, March, and May, 10 sampling points were added $1 \mathrm{~m}$ from some points; thus 35 samples were taken in each of those months. Sampling was conducted between 09:00 and 11:00 $\mathrm{h}$, to avoid water column mixing due to winds that typically occur after midday.

Estimating spatial variation, based on a hierarchical sampling strategy. To identify and characterize spatial variation of Myrionecta rubra from small to larger extents, the following survey was conducted. In September 2001, 73 samples were taken from 3 nested grids composed of one $4 \times 4 \mathrm{~m}^{2}$, one $40 \times 40 \mathrm{~m}^{2}$, and one $200 \times 200 \mathrm{~m}^{2}$ grid, with intersections at 1,10 , and $50 \mathrm{~m}$, respectively, located at Site C (Fig. 1, and see Fig. 7). Samples were taken between 09:00 and 11:00 h. Temperature, salinity, and transparency were also measured.

Statistical analysis of Myrionecta rubra spatial structure. Three methods were used to analyze the spatio-temporal distribution of $M$. rubra: regression, autocorrelation, and geostatistical analysis. These are outlined below.
Regression: This analysis assessed the effect of temperature, salinity, transparency, sampling site (location), and sampling time (seasonality) on the variability of Myrionecta rubra abundance at the lagoonal level. Location and seasonality were considered as discrete covariates with 10 (sampling sites) and 5 (mo) levels, respectively, and the other 3 variables were considered as continuous. Note that when continuous and discrete covariates are used in the same model, regression and covariance analysis are mathematically equivalent (Pearce 1982). A lineal model of the type:

$$
y_{i}=x_{i}^{T} \beta+\varepsilon_{i}
$$

was fit to the data obtained at the 10 sampling sites, at 5 times (i.e. $\mathrm{n}=50) . \quad x_{i}^{T}$ denotes a vector of covariate values associated with the ith datum, $\beta$ is a vector of coefficients measuring the effect of the covariates on abundance $y$, and $\varepsilon_{i}$ is a random error term with zero mean, constant variance $\sigma^{2}$ and covariance $\sigma_{i j}$ (between the $i$ th and $j$ th observations). To ensure that the coefficient related to any one site-season level was identifiable, we used the 'sum contrasts' method (Montgomery 1987).

As the covariates in Eq. (1) may be correlated, a principal component analysis of temperature, salinity, and transparency was performed. However, the coefficients for the principal components were not significantly different from 0 at a $5 \%$ significance level. Thus, these results were similar to those of Eq. (1) and are not reported.

The effects of seasonality (rainy and dry seasons) and of seawater entering through the sand-bar inlet on Myrionecta rubra abundance were also assessed by applying a multiple regression analysis to the 55 weekly data obtained at Site C. In this analysis we used standard multiple regression techniques (Neter et al. 1990) and applied functions in S-Plus (MathSoft) to the data.

Autocorrelation: An autocorrelation analysis (Diggle 1990) was applied to the data obtained at Site C $(\mathrm{n}=55)$ to detect temporal regularities in the distribution of Myrionecta rubra abundance, using S-Plus (MathSoft). This analysis estimates the autocorrelation function $\rho(t)$ of data observed along several points in time. $\rho(t)$ measures the correlation between observations made $t$ time intervals (or lags) apart. Because $\rho(t)$ is subject to sample variation, a confidence interval is computed to detect values of $\rho(t)$ that significantly differ from zero; e.g. for monthly data, a significant value for $\rho(6)$ would indicate a 6 mo period, and at $\rho(0)$ the value is 1 , as samples are correlated with themselves.

Geostatistics: The intensive systematic sampling, used to assess patchiness in this study, was designed to be analyzed by geostatistical techniques (see Bulit et 
al. 2003 for a simple review of these methods). Geostatistical analysis typically involves 2 steps. The first step is to describe the spatial structure of the studied variable, Myrionecta rubra abundance, in our case. In this work, spatial continuity was modelled using the variogram as the basic tool (Rossi et al. 1992). The second step is to apply the chosen variogram model to make predictions at non-visited locations, using a linear method of spatial prediction known as kriging (Goovaerts 1997). The applications of these 2 processes to this study are outlined below.

Structural analysis: Sampling occurred on several grids on 6 occasions (see 'Temporal changes of patchiness'). Methods to obtain empirical variograms followed those outlined by Bulit et al. (2003). Although several models were applied to the data, 2 standard omnidirectional models, plus a nugget effect, were used: the exponential and the Gaussian (see Isaaks \& Srivastava 1989 for formulae). These models were fit to the empirical variograms (see Cressie 1993), and the following parameters were estimated: (1) the nugget effect $\left(c_{0}\right)$, indicating the microscale variability at distances less than the shortest sampling distance, and measurement error; (2) the sill $\left(c_{0}+c\right)$, indicating the maximum level of variability; and (3) the range $a$, indicating the maximum distance at which patches are detected (see Bulit et al. 2003 and references therein for a more detailed explanation). Variograms were computed and modelled using S-Plus (MathSoft) and VARIOWIN (Pannatier 1996). Before interpolating by ordinary point kriging, the adopted variogram model along with a set of kriging parameters were cross-validated (Geo-Eas 1.2.1; Englund \& Sparks 1991; see Isaaks \& Srivastava 1989).

Kriging and conditional simulation: To describe patches within the sampling grids, the expected values of Myrionecta rubra abundance were estimated by ordinary point kriging (Goovaerts 1997). Patches were then mapped using Surfer 7.0 (Golden Software); patches were considered as the areas where abundance is above the cut-off of the 75th percentile of the kriging surface, following the criterion proposed by Bulit et al. (2003).

To describe patchiness at lagoonal level, estimations of the spatial distribution in May were obtained using conditional simulation (Ripley 1992), which is labourintensive but may provide more realistic estimates of spatial distribution than kriging, which smoothes interpolations (C. Díaz-Ávalos, C. Bulit \& D. J. S. Montagnes unpubl.). Conditional simulation is a statistical technique used to build representations of a phenomenon that are consistent with the observed data (introduced in the geostatistical literature by Davis 1987); for a description of the approaches to conditional simulation see Chilès \& Delfiner (1999).
Conditional simulation was used to simulate Myrionecta rubra abundance at unsampled locations, preserving the spatial variability: 200 conditional simulations were produced at 950 grid points inside the lagoon. To accomplish this, the initial conditioning values were: data taken at the 10 sampling sites (see Fig. 1), and data observed in the sampling grid located at the center of the lagoon in May (see Fig. 2). With both the observed and the simulated values, we classified a location as belonging to a $M$. rubra patch if its simulated value was above the third quartile (16.5 cells ml ${ }^{-1}$ ) of the observed values (as defined by Bulit et al. 2003). By summing over the 200 conditional simulations, we computed the probability of a patch at a location as the total number of times the site was classified as being inside a patch divided by 200 .

\section{RESULTS}

\section{Distribution of Myrionecta rubra at the lagoonal level}

Depth, temperature, salinity, and transparency for the 10 sampling sites fluctuated within and between sites and months. Site depth varied from 0.4 to $1.9 \mathrm{~m}$. Temperature varied from 26.5 to $32.0^{\circ} \mathrm{C}$. Salinity ranged between 0 and $34 \mathrm{psu}$. Transparency ranged from 0.2 to $1.9 \mathrm{~m}$.

Myrionecta rubra abundance was heterogeneous at the lagoonal level, ranging from 0 to 420 cells $\mathrm{ml}^{-1}$ (Fig. 2). Multiple regression analysis indicated a significantly higher abundance $(p=0.005)$ at Site 5 , in the north-west of the lagoon. In terms of temporal variation, $M$. rubra abundance exhibited a significant global decrease $(p=0.029)$ in $\mathrm{March}_{\text {; }}$ note that in March 2001 it was absent, except at Site 2 where abundance was $0.2 \mathrm{ml}^{-1}$. There were no trends in $M$. rubra abundance with salinity, temperature, or transparency.

Vertical profiles were taken 4 times at Site C, where the depth to the bottom was $\sim 1 \mathrm{~m}$. Profiles are only presented for October (late rainy season; Fig. 3a), January (dry season; Fig. 3b), and May (early rainy season; Fig. 3c), as Myrionecta rubra did not occur in March (dry season, see above). Temperature was constant with depth $\left(30,28\right.$, and $29^{\circ} \mathrm{C}$, respectively, in October, January, and May). In October, abundance was slightly elevated near the halocline but was relatively constant through the water column. In January and May, when the water column was mixed, there was an overall increase in abundance with depth. The entire water column, was well illuminated in October and May, assuming the euphotic zone is 2 to 2.7 times the Secchi depth (Parsons et al. 1977). The $0.4 \mathrm{~m}$ depth, used throughout this study to represent the water column, was reasonably representative but might provide underestimates of abundance at times. 


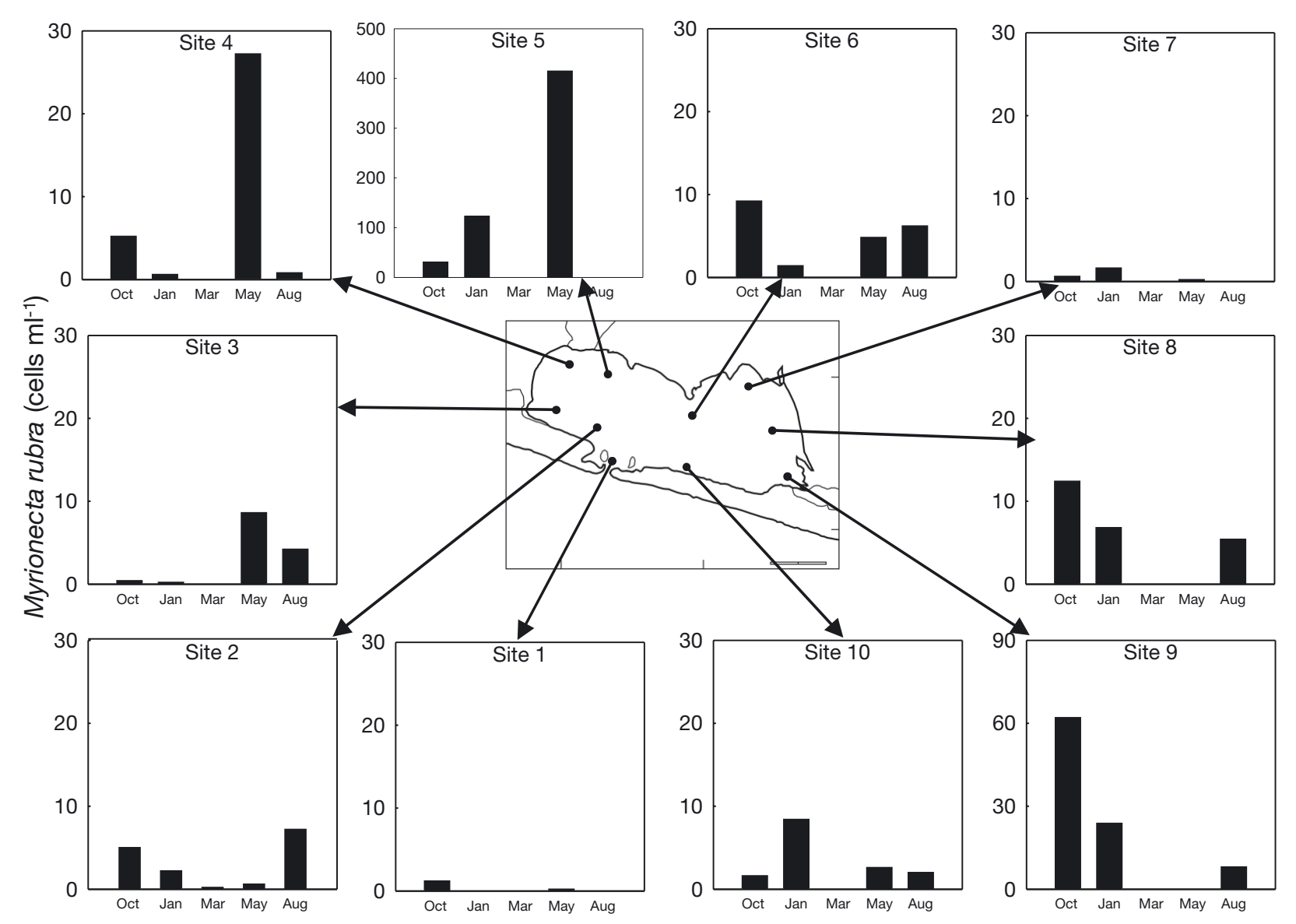

Fig. 2. Myrionecta rubra abundance (cells ml $\mathrm{m}^{-1}$ ) at 10 sampling sites (Fig. 1) over 5 mo. Note that abundance scale at Sites 5 and 9 differ from others

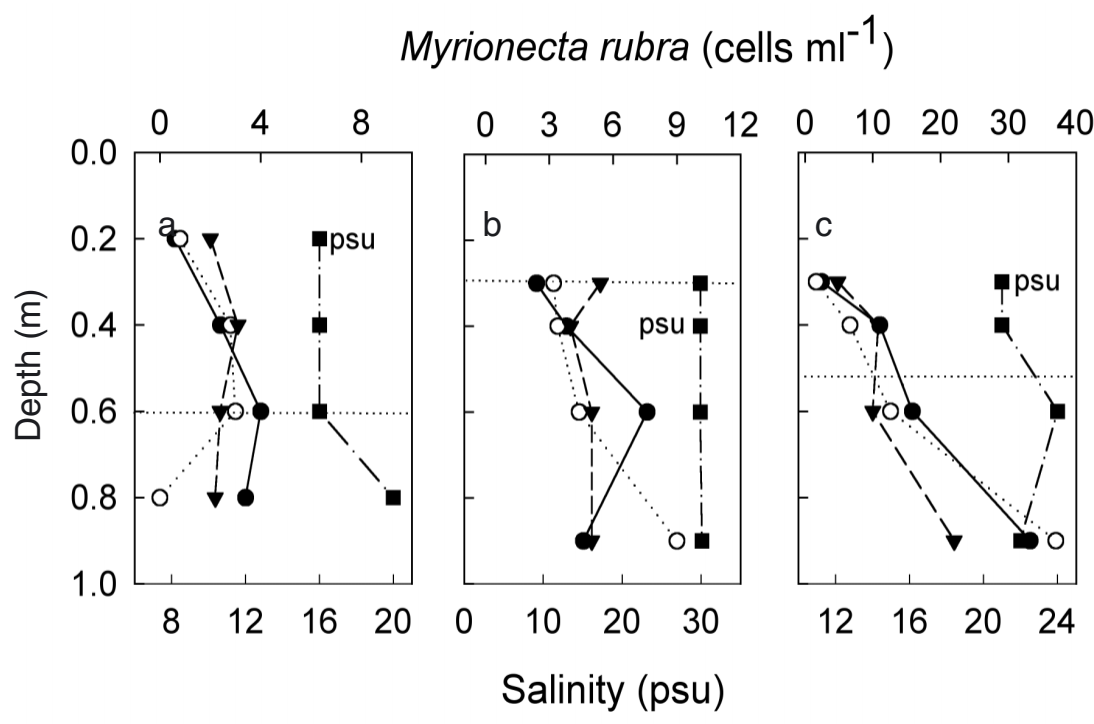

Fig. 3. Myrionecta rubra. Depth profiles of abundance and salinity in (a) October 2000, (b) January 2001, and (c) May 2001. The 3 profiles (M. rubra: open circles, solid circles, triangles; salinity: squares) were taken $10 \mathrm{~m}$ apart at Site C (Fig. 1). Dotted line indicates the Secchi disk depth. See 'Distribution and seasonal cycle of Myrionecta rubra' for further details

\section{Long-term fluctuation}

Myrionecta rubra abundance, measured over 55 wk, exhibited alternating periods of increase and decrease (Fig. 4). Multiple regression analysis indicated that ciliate abundance increased significantly $(\mathrm{p}=$ 0.027 ) during the rainy season, reaching a maximum of $\sim 350$ cells $\mathrm{ml}^{-1}$. No effect of the marine water input was detected.

The autocorrelation function $\rho(t)$ indicated a high temporal variability in Myrionecta rubra abundance at the lagoon center. Temporal correlation was significant only at 1 Lag 13 (Fig. 5), suggesting pulses in abundance ranging from $\sim 0$ to $>20$ cells $\mathrm{ml}^{-1}$, with a period of $\sim 3 \mathrm{mo}$. The function $\rho(t)$ also indicated that $M$. rubra patches persisted for $<1 \mathrm{wk}$ at the lagoon center; i.e. when successive points were positively correlated, the elapsed time between them indicated patch persistence. 


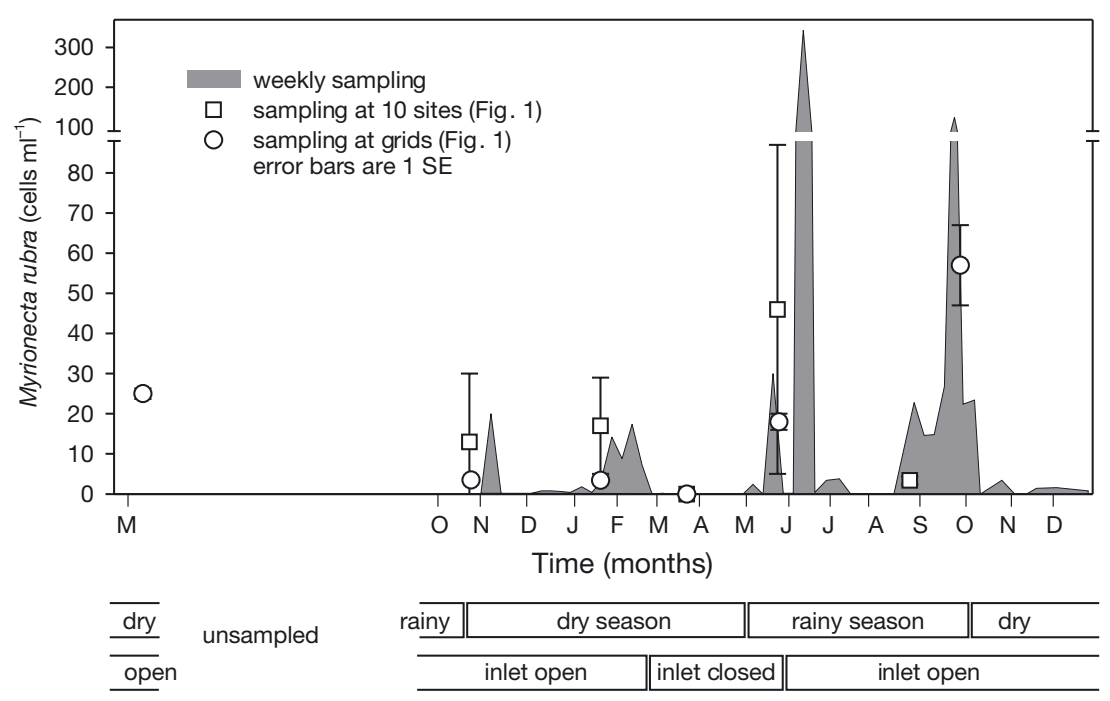

Fig. 4. Myrionecta rubra. Temporal variability in abundance based on different sampling strategies used. Grey regions: results of weekly samplings; mean abundance values of 10 sites (Fig. 1) are represented by squares. Open circles: mean values for the sampling grids (Site C, Fig. 1). A pilot sampling conducted in March 2000 is also shown. Error bars $=1 \mathrm{SD}$

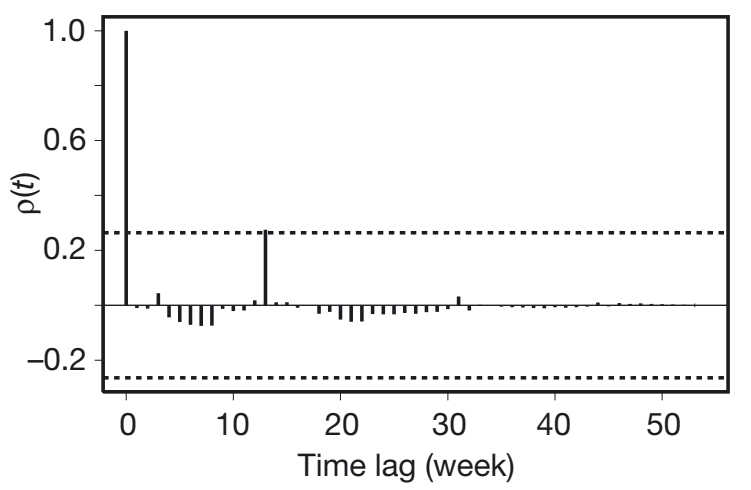

Fig. 5. Myrionecta rubra. Autocorrelation function $\rho(t)$ of weekly abundance at Site C (Fig. 1). Horizontal dashed lines are $\sim 95 \%$ CIs for the significance of each autocorrelation estimate. $\rho(13)(\rho[13 \mathrm{mo}])$ falls beyond the $95 \%$ limit, indicating that a recurrent spatial structure occurred with that periodicity. Note that the first autocorrelation value represents the correlation of an observation with itself

\section{Patch characterization through time}

Mean abundances varied in the sample grids by 20-fold between months; Myrionecta rubra did not occur in March 2001 (Table 1). Salinity was also variable, whereas temperature and transparency were relatively constant (Table 2). In October 2000 and September 2001, the water was stratified with a halocline at $0.6 \mathrm{~m}$, but during the other surveys the water column was mixed.

Empirical and model variograms were obtained for discrete sampling grids (Fig. 6). Pure nugget models fit the data in March and October 2000 and September
2001 (4 m scale; Fig. 6a,b,e), indicating that patches were not detected. The January and May variograms (Fig. 6c,d) indicated that patches of Myrionecta rubra extended over a range of $\sim 20$ and $10 \mathrm{~m}$, respectively, whereas in September (Fig. 6f,g), patches of $M$. rubra extended over a range of $\sim 130$ and $80 \mathrm{~m}$, respectively.

Although the September variogram at the $200 \mathrm{~m}$ sampling scale (Fig. 6g) was the most structured $(86 \%$ of the total variance is explained by the Gaussian model; Table 1), it failed to provide information at small lags. In contrast, the May variogram (Fig. 6d) was also highly structured (70\% of spatial structure explained by the model; Table 1) and provided variogram values at smaller lags. Gaussian models best fit the data for January, May and September at the $200 \mathrm{~m}$ scale (Fig. 6c,d,g). After crossvalidation analysis, an exponential model with a relatively high nugget best fit the data for September at the $40 \mathrm{~m}$ scale (Fig. 6f). However, as the model depicted a weak spatial structure, we compared its sum of squares (27100) with that of a pure nugget model (45600), and as the sum of squares of the former was $<60 \%$ of the latter, we selected the exponential model. The lack of estimates at short lags for the September variogram at 200 m made us doubt the fit of the model: the choice of a Gaussian model was supported by the model fit to the combination of 3 nested grids (see below, 'Assessing patchiness at nested, hierarchical observational scales' and Fig. 7c). Details of the model parameters and of cross validation results are indicated in Table 1.

Myrionecta rubra was distributed in well-defined patches (i.e. water parcels where abundance is above the cut-off of the upper quartile; Bulit et al. 2003), as indicated on the kriging maps (grey shading, Fig. $6 \mathrm{~h}, \mathrm{i}, \mathrm{j}, \mathrm{k})$. Predicted patches for May and September at the $200 \mathrm{~m}$ scale (Fig. 6i,k) indicate a concentrated distribution in a single patch; these patches were structured, i.e. abundance changed regularly for a given distance. In contrast, the patch at the $40 \mathrm{~m}$ scale (Fig. 6j) was more dense, but less structured.

\section{Assessing patchiness at nested, hierarchical observational scales}

Myrionecta rubra abundance changed over 1 order of magnitude (20 to 250 cells ml $\mathrm{m}^{-1}$ ) on the $4 \times 4 \mathrm{~m}^{2}$ grid and over $\sim 3$ orders of magnitude on the $200 \times 200 \mathrm{~m}^{2}$ water parcel (1 to 700 cells $\mathrm{ml}^{-1}$ ). In contrast, the change on the $40 \times 40 \mathrm{~m}^{2}$ grid was $<5$-fold $(20$ to 
Table 1. Myrionecta rubra. Statistics ( $\bar{x}$ mean, measured as cells $\mathrm{ml}^{-1}$ ) and parameters of variogram models fit to abundance for several months. $C_{0}$ : nugget effect; $c_{0}+C$ : sill; $a$ : range. The spatially structured component corresponds to the ratio $c /\left(c_{0}+c\right) \times 100$. Cross-validation results of models and parameters selected to predict $M$. rubra abundance by ordinary kriging (see Bulit et al. 2003 for details on kriging parameters): bias $=$ mean prediction error; MSE (mean squared error) $=\mathrm{SD}^{2}+$ bias $^{2}$. See models (Fig. 6)

\begin{tabular}{|c|c|c|c|c|c|c|c|c|c|c|c|c|}
\hline \multirow[t]{2}{*}{ Month } & \multicolumn{2}{|c|}{ Abundance } & \multirow[t]{2}{*}{ Model } & \multicolumn{3}{|c|}{ —Parameters — } & \multirow{2}{*}{$\begin{array}{c}\text { Spatially } \\
\text { structured } \\
\text { component (\%) } \\
\text { (m) }\end{array}$} & \multicolumn{2}{|c|}{ Kriging parameters } & \multicolumn{3}{|c|}{-Model statistics -} \\
\hline & $\bar{X}$ & $\mathrm{SD}$ & & $\begin{array}{l}C_{0} \\
\text { (cel }\end{array}$ & $\begin{array}{c}C_{0}+C \\
\left.\mathrm{ml}^{-1}\right)^{2}\end{array}$ & $\begin{array}{c}a \\
(\mathrm{~m})\end{array}$ & & Radius & Points & Bias & SD & MSE \\
\hline Mar 00 & 25.03 & 6.52 & Pure nugget & 42 & 42 & 0 & 0 & & & & & \\
\hline Oct 00 & 3.52 & 1.24 & Pure nugget & 1.35 & 1.35 & 0 & 0 & & & & & \\
\hline Jan 01 & 3.37 & 1.59 & Gaussian & 1.1 & 2.8 & 23 & 61 & 15 & 15 & -0.02 & 1.51 & 2.30 \\
\hline May 01 & 17.86 & 10.0 & Gaussian & 38 & 125 & 9 & 70 & 15 & 10 & -0.41 & 10.11 & 102.40 \\
\hline Sep 01 (4 m) & 60.85 & 40.36 & Pure nugget & 2010 & 2010 & 0 & 0 & & & & & \\
\hline Sep $01(40 \mathrm{~m})$ & 56.32 & 13.62 & Exponential & 90 & 270 & 129 & 67 & 12 & 4 & 0.20 & 11.90 & 141.65 \\
\hline Sep $01(200 \mathrm{~m})$ & 52.08 & 138.63 & Gaussian & 3000 & 21000 & 83 & 86 & 50 & 8 & -0.90 & 156.06 & 24355.50 \\
\hline
\end{tabular}

90 cells $\mathrm{ml}^{-1}$ ). Mean abundances for the 3 grid sizes were similar (Table 3 ).

For both the $4 \times 4 \mathrm{~m}^{2}$ and the $40 \times 40 \mathrm{~m}^{2}$ grid (that includes the $4 \times 4 \mathrm{~m}^{2}$ grid), the variograms indicate a pure nugget effect, suggesting a random spatial structure (Fig. 7a,b). Thus, the variograms could not be used to model the distribution (Fig. $7 \mathrm{~b}$ and Table 3). However, combining the 3 hierarchical grids to estimate 1 variogram produced a detailed assessment of patches (Fig. $7 \mathrm{C}$ ), and when all data were included patches were structured with a maximum size of $\sim 170 \mathrm{~m}$. The corresponding kriging map indicated 2 patches, one of high abundance, increasing rapidly over $\sim 10$ s of m (Fig. $7 \mathrm{~d}$ ).

\section{Patchiness at lagoonal level}

Conditional simulation of patches indicate, in May, the probability of a Myrionecta rubra patch covering most of the western lagoon, over $\sim 2 \mathrm{~km}$ (Fig. 8). May was chosen for this simulation as the variogram was highly structured in this month (see 'Patch characterization

Table 2. Hydrological data at grid sites on different months; surface (s) and bottom (b) water-level values are indicated

\begin{tabular}{|lcccccc|}
\hline Date & $\begin{array}{c}\text { Depth } \\
(\mathrm{m})\end{array}$ & Level & $\begin{array}{c}\text { Temp. } \\
\left({ }^{\circ} \mathrm{C}\right)\end{array}$ & $\begin{array}{c}\text { Salinity } \\
(\mathrm{psu})\end{array}$ & $\begin{array}{c}\text { Transparency } \\
(\mathrm{m})\end{array}$ & Barier inlet \\
\hline 25 Oct 00 & \multirow{2}{*}{1.10} & $\mathrm{~s}$ & 30 & 26 & 0.6 & Open \\
& & $\mathrm{b}$ & 30 & 20 & 0.6 & Open \\
23 Jan 01 & \multirow{2}{*}{1.10} & $\mathrm{~s}$ & 29 & 30 & 0.3 & Open \\
& & $\mathrm{b}$ & 28 & 30 & 0.3 & Open \\
24 Mar 01 & \multirow{2}{*}{ 1.50 } & $\mathrm{s}$ & 29 & 29 & 0.5 & Closed \\
& & $\mathrm{b}$ & 29 & 31 & 0.5 & Closed \\
27 May 01 & \multirow{2}{*}{ 1.10 } & $\mathrm{s}$ & 29 & 21 & 0.5 & Closed \\
& & $\mathrm{b}$ & 29 & 22 & 0.5 & Closed \\
30 Sep 01 & \multirow{2}{*}{1.10} & $\mathrm{~s}$ & 29 & 0 & 0.3 & Open \\
& & $\mathrm{b}$ & 29 & 5 & 0.3 & Open \\
\hline
\end{tabular}

through time', Fig. 6d), and supportive data exist from the 10 sampling sites (Fig. 2). The distribution (Fig. 8) indicates only the probability of a lagoon site being classified as part of a patch; following recommendations of C. Díaz-Ávalos, C. Bulit \& D. J. S. Montagnes (unpubl.), we chose a probability level of $\mathrm{p}>0.42$, beyond which a site is considered part of a patch. Using $p>0.42$, we indicate the presence of a single patch covering $\sim 25 \%$ of the lagoon (Fig. 8). Note, though, that patches are dynamic in space and time, and Fig. 8 represents only 1 discrete spatial distribution.

\section{DISCUSSION}

The persistence and growth of Myrionecta rubra populations in the lagoon, as in any water body, will inevitably be linked to its distribution, at a variety of scales. This study, therefore, assessed the patchiness of this potentially important species: we have characterized $M$. rubra horizontal patchiness at different spatial and temporal scales, and then provided an indication of how patchiness might be driven by physicalchemical factors and physiologicalbehavioural properties of the organism.

\section{Spatial and temporal abundance at the lagoonal level}

The lagoonal abundance of Myrionecta rubra was similar to that described over a wide range of ecosystems (Margalef 1975, Packard et al. 1978, Montagnes \& Lynn 1989, Sorokin et al. 1999, 2003, Modigh 2001). However, we have established that $M$. rubra abundance exhibited both temporal 


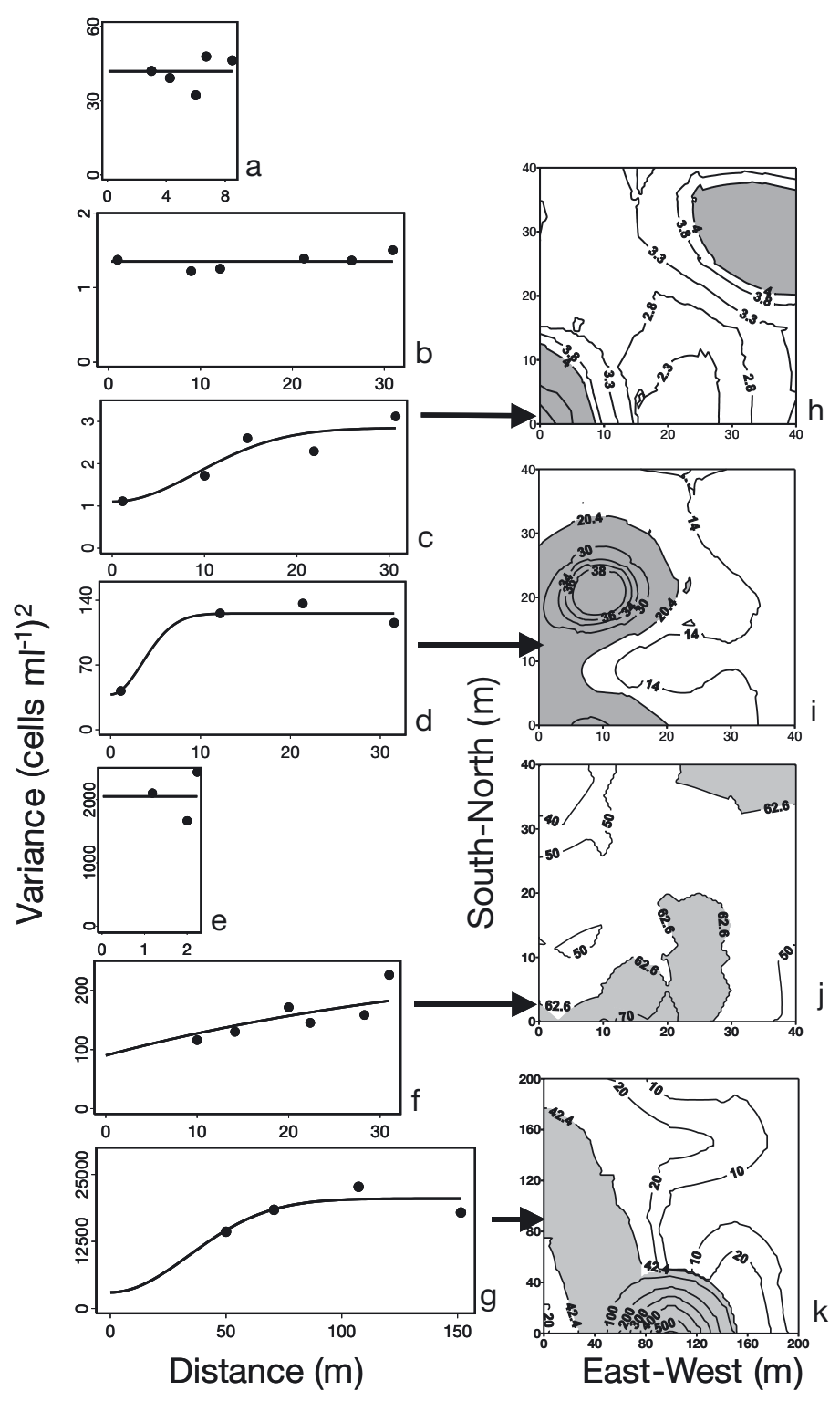

Fig. 6. Myrionecta rubra patches at Site C (Fig. 1) through different months, as indicated by variograms $(\mathrm{a}-\mathrm{g})$ and kriging maps predicted from them $(\mathrm{h}-\mathrm{k})$. Empirical variograms for March, October, and September at the $4 \mathrm{~m}$ scale were fit by a pure nugget model (lines in a, b, and e, respectively). Empirical variograms for January, May, and September at the $200 \mathrm{~m}$ scale were fit by a Gaussian model (lines in c, d, and $\mathrm{g}$, respectively). The empirical variogram for September at the $40 \mathrm{~m}$ scale was fit by an exponential model (line in f). Note that $x$-axis of the variograms is not scaled; differently sized variograms indicate relative grid differences. On the kriging predictions maps, grey shading represents patches of $M$. rubra (see 'Patch characterization through time'). Isolines indicate $M$. rubra abundance (cells $\mathrm{ml}^{-1}$ )

and spatial patchiness ranging from 0 to $350 \mathrm{cells} \mathrm{ml}^{-1}$ and from 0 to 700 cells ml $^{-1}$, respectively. These trends were revealed using several approaches that are discussed below.

This work assessed horizontal variability, but our analysis is potentially influenced by vertical variation, as we focused on 1 depth $(0.4 \mathrm{~m})$, and there is the potential for vertical heterogeneity. However, in general, vertical distribution of Myrionecta rubra was relatively homogeneous over time (Fig. 3). Furthermore, due to the lagoon shallowness, vertical density gradients produce a tendency for the major water motion to be extended on the horizontal plane (Mee 1977), and horizontal flows are likely to be more influential than vertical ones in driving plankton distribution (Margalef 1969). Moreover, the water column was mixed daily by inshore winds, reducing the potential for large-scale vertical patches (Mee 1977), and the bottom was usually within the euphotic zone, reducing the likelihood of phototactically induced M. rubra migration (Lindholm 1985). We have, therefore, focused on horizontal and temporal distributions based on 1 representative depth.

Myrionecta rubra occurred over a wide range of salinity and temperature, and although these abiotic factors varied in the lagoon, multiple regression suggested that neither controlled the distribution; this

Table 3. Geostatistical models, parameters and cross validation results of nested grids in September. Legend details as in Table 1. See models and kriging prediction maps on Fig. $7 . \bar{x}$ mean, measured as cells $\mathrm{ml}^{-1} ; c_{0}$ : nugget effect; $c_{0}+c$ : sill; $a$ : range. The spatially structured component corresponds to the ratio $c /\left(c_{0}+c\right) \times 100$

\begin{tabular}{|c|c|c|c|c|c|c|c|c|c|c|c|c|}
\hline \multirow{3}{*}{$\begin{array}{l}\text { Sep nested } \\
\text { grids }\left(\mathrm{m}^{2}\right) \\
4 \times 4\end{array}$} & \multicolumn{2}{|c|}{ Abundance } & \multirow[t]{2}{*}{ Model } & \multicolumn{3}{|c|}{ —Parameters_- } & \multirow{2}{*}{$\begin{array}{l}\text { Spatially structured } \\
\text { component }(\%) \\
\text { (m) }\end{array}$} & \multicolumn{2}{|c|}{ Kriging parameters } & \multicolumn{3}{|c|}{ Model statistics } \\
\hline & $\bar{X}$ & $\mathrm{SD}$ & & $\begin{array}{l}C_{0} \\
\text { (cel }\end{array}$ & $\begin{array}{r}C_{0}+C \\
\left.\mathrm{ml}^{-1}\right)^{2}\end{array}$ & $a$ & & $\begin{array}{l}\text { Radius } \\
\text { (m) }\end{array}$ & Points & Bias & SD & MSE \\
\hline & 60.85 & 40.37 & Pure nugget & 2010 & 2010 & 0 & 0 & & & & & \\
\hline $\begin{array}{l}40 \times 40 \\
\text { and } 4 \times 4\end{array}$ & 59.31 & 29.77 & Pure nugget & 850 & 850 & 0 & 0 & & & & & \\
\hline $\begin{array}{l}200 \times 200 \\
\text { and } 40 \times 40 \\
\text { and } 4 \times 4\end{array}$ & 57.33 & 83.63 & Gaussian & 1000 & 7600 & 173 & 87 & 50 & 4 & 0.53 & 94.73 & 8974.05 \\
\hline
\end{tabular}



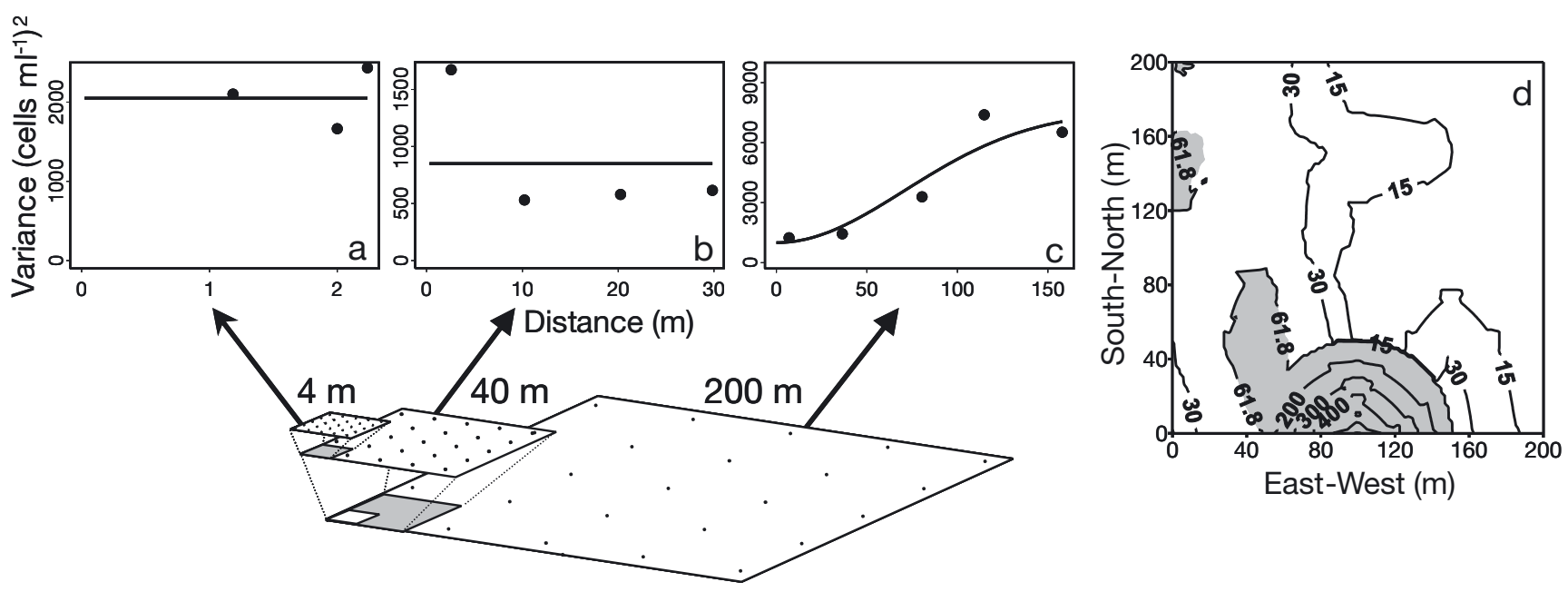

Fig. 7. Perspective sketch of the nested sampling design at 4, 40, and $200 \mathrm{~m}$ scales indicated by the successive squares; shaded areas show the relative size and the location of the nested grids; the circles mark the sampling sites. Variograms and the kriging map were calculated for each grid (the variogram for the $40 \times 40 \mathrm{~m}^{2}$ grid data includes data from the $4 \times 4 \mathrm{~m}^{2}$ grid, and the variogram for the $200 \times 200 \mathrm{~m}^{2}$ grid includes data from the $40 \times 40$ and the $4 \times 4 \mathrm{~m}^{2}$ grids). Empirical variograms estimated for the smallest grid data (points in a) and mid-sized grid data (points in b) were fit by a pure nugget model (lines in a and b). The empirical variogram estimated for the largest grid data (points in c) was fit by a Gaussian model (line in c); using the parameters of this model, a kriging prediction map (d) indicated Myrionecta rubra patches (grey shading)

agrees with Lindholm (1985), who suggested that $M$. rubra is not influenced by temperature or salinity. Multiple regression, however, did indicate a higher abundance in the north-west (NW) of the lagoon and a global decrease in March during the dry season. In the $\mathrm{NW}$, high nutrient concentrations (e.g. $\mathrm{NH}_{4}{ }^{+}$: 34 to $70 \mu \mathrm{M}$ ) occur during the rainy season (Soto-Castor et al. 2002). $\mathrm{NH}_{4}{ }^{+}$appears to be the preferential source of

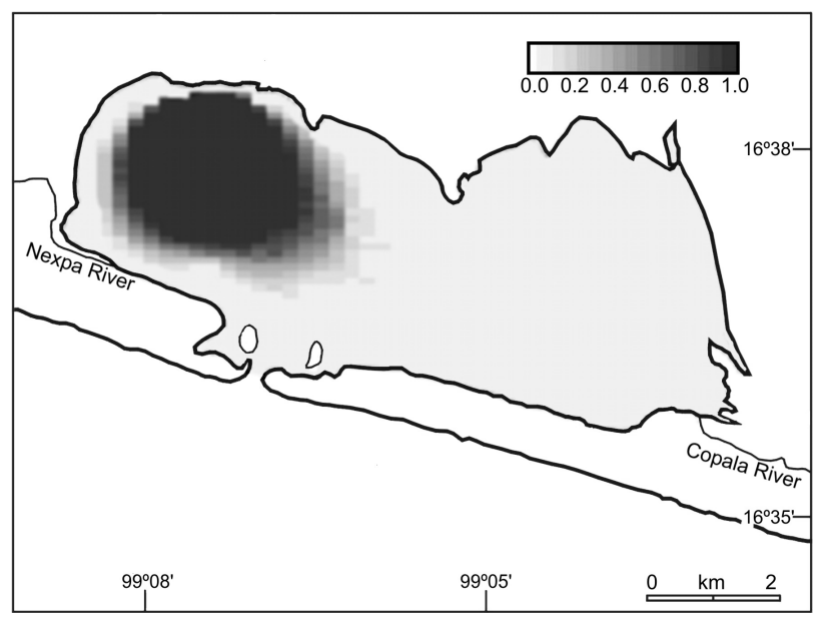

Fig. 8. Map obtained using conditional simulation for May data, showing the probability of finding a Myrionecta rubra patch in the lagoon. Scale (0 to 1 ) indicates the probability for any site in the lagoon to be considered part of the patch. See 'Patchiness at lagoonal level' for details on the definition of a patch nitrogen during the development of $M$. rubra blooms (Daneri et al. 1992), and endosymbionts borne by the ciliate use ammonium under both light and dark conditions (Wilkerson \& Grunseich 1990). Ammonium regeneration is most likely to occur in the NW, at the water-silt-clay sediment interface, which releases nutrients into the water (Mee 1978, Soto-Castor et al. 2002). This may have stimulated growth and resulted in high $M$. rubra abundance in this region.

Thus, in general, patchiness at the lagoonal scale may, in part, be influenced by nutrient supply. Allochthonous input occurs on a scale of $\sim 6$ mo due to the freshwater inputs (Mee 1978); this may explain the seasonal (temporal) peak during the rainy season (Fig. 4). In contrast, autochthonous input potentially occurs daily, originating from bacterially mediated nutrient regeneration in sediments (Mee 1978), and resuspension by winds; this may maintain higher Myrionecta rubra abundance in the NW region. In general, the suggestion that a combination of allochthonous nutrient input and large-scale water stability will result in large-scale blooms of M. rubra (Cloern et al. 1994) is upheld by our analysis.

Myrionecta rubra abundance also exhibited a temporal, pulse-like pattern (Fig. 4). Autocorrelation revealed a recurrent abundance structure, with a 13 wk periodicity (Fig. 5). The $\sim 3$ mo cycle may not be associated with the nutrient supply, as it persisted over both dry and rainy seasons (over which allochthonous input would vary). Dominant temporal scales may be set by predator-prey interactions (Steele 1978); thus, we speculate that this pulse cycle 
might be associated with rapid growth of the ciliate and grazing by zooplankton. The cycle might then be linked to generation time and mortality of the grazers, since in nutrient-enriched ecosystems, ciliate assemblages can be top-down controlled by predators (Nielsen \& Kiørboe 1991). For instance, a 50 d dominant time scale in ciliate abundance, estimated using geostatistical analysis, has been related to a complex bottom-up and top-down control in Mediterranean waters (Vaqué et al. 1997).

We might hypothesize that copepods, such as Acartia and Paracalanus, that can be abundant in coastal regions (Pagano \& Saint-Jean 1994, Palomares et al. 1998, Kouassi et al. 2001) and have generation times on the order of 19 to $50 \mathrm{~d}$ (Chisholm \& Roff 1990, Breteler \& Schogt 1994), control ciliate abundance; they, in turn, are eaten by fish (Yáñez-Arancibia 1978). Thus, there may be a trophic cascade effect (Pace et al. 1998), resulting in periodic pulses of the predator and prey.

We thus speculate that high abundance at the large scale may be determined on a seasonal level by allochthonous nutrients, and may be maintained by nutrient resuspension. Furthermore, temporal predator-prey oscillations may interact with the large scale dynamics on a $\sim 3$ mo cycle. Thus, Myrionecta rubra production may continue up the food chain, potentially leading to fish production.

\section{Spatial structure of patches}

Geostatistics provided a useful tool for quantifying Myrionecta rubra patchiness. Patch size in the lagoon changed through time, and our statistical analysis is supported by less rigorous global observations (Table 4). Most of the models used to fit Myrionecta rubra variograms were Gaussian, suggesting that the patches formed by $M$. rubra fade out smoothly at the patch edges due to the higher continuity of Gaussian processes (Armstrong 1998, Roa \& Tapia 2000). Note, however, that M. rubra formed discrete patches of different size. Distinct patches, with regions of high numbers of M. rubra adjacent to regions of very low concentration, as detected in this work, have been previously noted (Table 4). M. rubra showed no spatial structure for 3 surveys (Fig. 6); this can be attributed to the relatively low resolution in sampling and to the lack of sampling points at a distance smaller than the spacing between consecutive grid nodes. Although geostatistical analysis can rely on any distribution of sites, located at varying distances, it was pragmatic, in terms of sampling effort and design, to sample a nested grid in a systematic fashion.

The nested sampling design revealed patterns in the Myrionecta rubra distribution that would have been undetected with less rigorous sampling techniques. When the sampling scale was modified, the spatial pattern changed. Whereas at the smaller extents, $M$. rubra distribution was homogeneous, the extent-increase allowed the identification of a $170 \mathrm{~m}$ patch; a similar regularity has been detected in communities of benthic ciliates, where different types of patterns changed along the scale of study, from a random mosaic at a small scale to several levels of patchiness at larger scales (Azovsky 2000).

The hierarchical-nested grid method of sampling thus appears to provide a useful, relatively low-labour means to assess patches. Most of the spatial dependence was encompassed by the intensive sampling coverage, as indicated by the small nugget variance of the fit model. Moreover, including data from the 2 smaller subgrids provided valuable information regarding the variogram behaviour near the origin (cf. Fig. $6 \mathrm{~g}$ with Fig. $7 \mathrm{c}$ ), and increased the range over which patches are expected. In contrast, the larger scaling provided valuable information regarding the sill.

Table 4. Myrionecta rubra patches in different locations. In most studies, patch size is the result of visual observation; at times, patches are qualified as 'large', as in the Kuwait Bay case, without providing dimensions. In 2 cases, abundance was not determined (nd), and M. rubra biomass was estimated by chl a concentration. The discreteness was visually assessed by the authors and supported by sampling in- and outside the patch

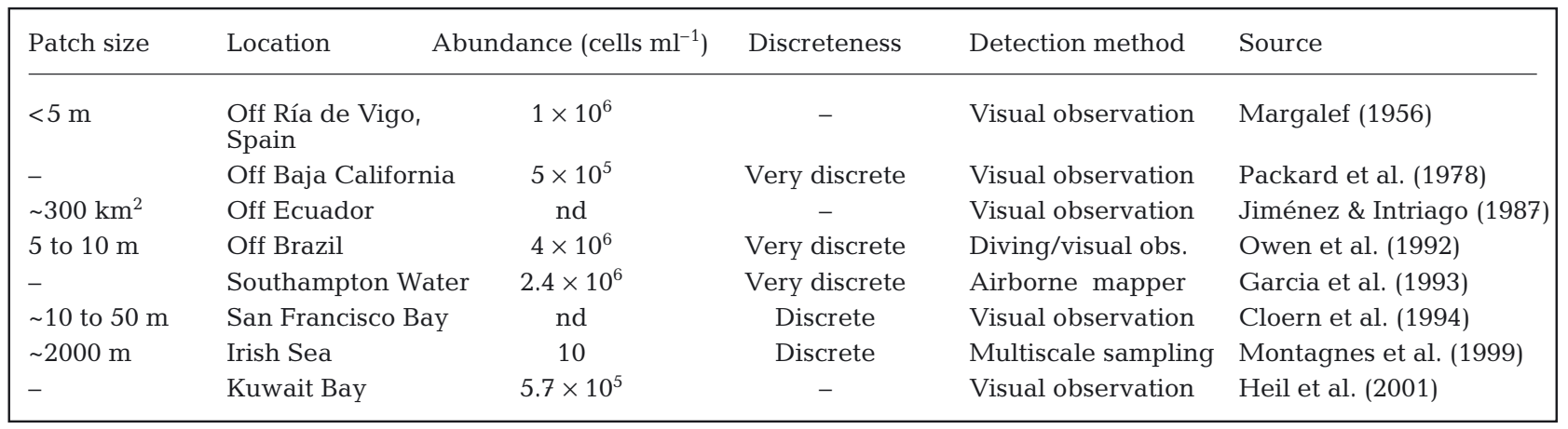




\section{Ecological implications of patchiness scales in the lagoon}

Three spatial scales of Myrionecta rubra patches were identified in the lagoon: large ( $>1000 \mathrm{~m}$ ), meso (100 to $1000 \mathrm{~m}$ ), and fine (1 to $100 \mathrm{~m}$ ) scale. Below, we assess the unique attributes associated with each scale, which in turn provide insight into their formation.

Large-scale ( 2000 m) patches of Myrionecta rubra (e.g. Fig. 8) emerged after processing a large number of conditional simulations, used for the first time to assess patches at the large scale. These patches are likely related to abiotic processes associated to basin morphometry and size, wind regime, and current patterns (Pinel-Alloul et al. 1999); furthermore, fresh- and marine water influx may generate patchiness in this lagoon; seasonal variations in allochthonous nutrient inputs will stimulate maximal growth of $M$. rubra. The high nutrient content of the river discharge in this area, together with the restrictive northwards mixing of the waters from the Nexpa River (Mee 1977), may explain the localized large-scale patch in the western lagoon (Fig. 8).

At the mesoscale (100 to $1000 \mathrm{~m})$, Myrionecta rubra formed patches of 130 and $170 \mathrm{~m}$ (Fig. 6). At this scale, besides the dissipation of larger patches, some abiotic generative processes may include wind current patterns and downwind accumulation (Pinel-Alloul et al. 1999). Furthermore, migration and growth may be biotic factors contributing to patch formation at this scale (Crawford \& Lindholm 1997).

At the fine scale (1 to $100 \mathrm{~m})$, patches of 10,20 , and $80 \mathrm{~m}$ occurred (Fig. 6). These patches may be formed and advected several times a day by physical processes such as Langmuir vortices and physical gradients (Powell et al. 1975). The sea-breeze-land-breeze cycle resulting from daily heating imposes a strong daily periodicity that may stimulate these patches (Mee 1977, Denman \& Powell 1984). It is unlikely that these patches result from population growth, as the maximum growth rate of Myrionecta rubra is $\sim 0.8 \mathrm{~d}^{-1}$ (Crawford et al. 1997). In contrast, migration of $M$. rubra (>5 $\mathrm{mm} \mathrm{s}^{-1}$, Lindholm 1985) may provide the convergent velocity needed to produce patches (Crawford \& Purdie 1992).

Although the resolution of this study was insufficient to assess them, we consider it essential to mention microscale patches $(<1 \mathrm{~m})$. Recent work has emphasized phytoplankton patchiness at $\mathrm{cm}$ scales (Seuront et al. 1996, Franks \& Jaffe 2001, Lovejoy et al. 2001, Waters et al. 2003), and ciliate patches 1 to $2 \mathrm{~cm}$ in size occur (Taylor \& Berger 1980, Kils 1993). Abiotic and biotic processes such as convection currents, smallscale nutrient patches (Seuront et al. 2002), reproductive behaviour, predator avoidance, prey/predator ratio, and escape response may be involved in microscale patches generation. Most of these mecha- nisms can apply to Myrionecta rubra populations in the lagoon. A future challenge would be to design unobtrusive methods of sampling so that geostatistics may be applied at this scale; possibly in situ video microscopy is the answer (Davis et al. 1992).

The concept that patch structure in pelagic ecosystems is generated at larger scales and then patches are propagated at smaller scales patches has recently been challenged (Waters et al. 2003). Our work both supports and refuses this concept. We have proposed that, in fact, Myrionecta rubra patches may originate by fragmentation of larger patches, but we have also suggested that they form by growth of smaller patches, and by physical-behavioural aggregation of cells. We have also speculated on the mechanism generating spatial structure of these patches. Now that the existence of patches has been recognized and, to some extent, quantified, the next challenge is to assess their role in primary production, both as food for grazers and as a means to exploit the environment (Brentnall et al. 2003).

Acknowledgements. This paper forms part of the $\mathrm{PhD}$ thesis of C.B. at the University of Liverpool and Universidad Autónoma Metropolitana-Xochimilco. We thank Dr. Martha Signoret for her constructive comments on the manuscript. We also thank Javier Cruz-Hernández, Eusebio Cueva and Lee Patchell for their assistance during fieldwork. Finally, we thank 2 anonymous reviewers for their constructive comments.

\section{LITERATURE CITED}

Armstrong M (1998) Basic linear geostatistics. SpringerVerlag, Berlin

Azovsky A (2000) Concept of scale in marine ecology: linking the words or the worlds? Web Ecol 1:28-34

Brentnall SJ, Richards KJ, Brindley J, Murphy E (2003) Plankton patchiness and its effect on larger-scale productivity. J Plankton Res 25:121-140

Breteler WCMK, Schogt N (1994) Development of Acartia clausi (Copepoda, Calanoida) cultured at different conditions of temperature and food. Hydrobiologia 292: 469-479

Bulit C, Díaz-Ávalos C, Signoret M, Montagnes DJS (2003) Spatial structure of planktonic ciliate patches in a tropical coastal lagoon: an application of geostatistical methods. Aquat Microb Ecol 30(2):185-196

Chilès JP, Delfiner P (1999) Geostatistics: modeling spatial uncertainty. Wiley Interscience, New York

Chisholm LA, Roff JC (1990) Abundances, growth rates and production of tropical neritic copepods off Kingston, Jamaica. Mar Biol 106:79-89

Cloern JE, Cole BE, Hager SW (1994) Notes on Mesodinium rubrum red tide in San Francisco Bay (California, USA). J Plankton Res 16:1269-1276

Crawford DW (1989) Mesodinium rubrum: the phytoplankter that wasn't. Mar Ecol Prog Ser 58:161-174

Crawford DW, Lindholm T (1997) Some observations on vertical distribution and migration of the phototrophic ciliate Mesodinium rubrum (= Myrionecta rubra) in a stratified brackish inlet. Aquat Microb Ecol 13:267-274 
Crawford DW, Purdie DA (1992) Evidence for avoidance of flushing from an estuary by a planktonic, phototrophic ciliate. Mar Ecol Prog Ser 79:259-265

Crawford DW, Purdie DA, Lockwood APM, Weissman P (1997) Recurrent red-tides in the Southampton Water estuary caused by the phototrophic ciliate Mesodinium rubrum. Estuar Coast Shelf Sci 45(6):799-812

Cressie N (1993) Statistics for spatial data. John Wiley, New York

Daneri G, Crawford DW, Purdie DA (1992) Algal blooms in coastal waters: a comparison between two adaptable members of the phytoplankton, Phaeocystis sp. and Mesodinium rubrum. Sci Total Environ(Suppl):879-890

Davis CS, Gallager SM, Solow AR (1992) Microaggregations of oceanic plankton observed by towed video microscopy. Science 257:230-232

Davis MW (1987) Production of conditional simulations via the LU triangular decomposition of the covariance matrix. Math Geol 19:91-98

Denman KL, Powell TM (1984) Effects of physical processes on planktonic ecosystems in the coastal ocean. Oceanogr Mar Biol Annu Rev 22:125-168

Diggle PJ (1990) Time series: a biostatistical introduction. Clarendon, Oxford

Englund E, Sparks A (1991) GEO-EAS 1.2.1 user's guide. Environmental Protection Agency, Las Vegas

Fasham MJR (1978) The statistical and mathematical analysis of plankton patchiness. Oceanogr Mar Biol Annu Rev 16: 43-79

Franks PJS, Jaffe JS (2001) Microscale distributions of phytoplankton: initial results from two-dimensional imaging fluorometer, OSST. Mar Ecol Prog Ser 220:59-72

Franks PJS, Walstad LJ (1997) Phytoplankton patches at fronts: a model of formation and response to wind events. J Mar Res 55:1-29

Garcia CAE, Purdie DA, Robinson IS (1993) Mapping a bloom of the photosynthetic ciliate Mesodinium rubrum in an estuary from airborne thematic mapper data. Estuar Coast Shelf Sci 37:287-298

García E (1973) Modificaciones al sistema de Köppen para adaptarlo a las condiciones de la República Mexicana. Universidad Nacional Autónoma de México, Mexico DF

Goovaerts P (1997) Geostatistics for natural resources evaluation. Oxford University Press, New York

Harris GP (1980) Temporal and spatial scales in phytoplankton ecology: mechanisms, methods, models, and management. Can J Fish Aquat Sci 37:877-900

Haury LR, McGowan JA, Wiebe PH (1978) Patterns and processes in the time-space scales of plankton distributions. In: Steele JH (ed) Spatial pattern in plankton communities. Plenum Press, New York, p 277-327

Heil CA, Glibert PM, Al-Sarawl MA, Faraj M, Behbehani M, Husain M (2001) First record of a fish-killing Gymnodinium sp. bloom in Kuwait Bay, Arabian Sea: chronology and potential causes. Mar Ecol Prog Ser 214:15-23

Isaaks EH, Srivastava RM (1989) An introduction to applied geostatistics. Oxford University Press, New York

Jiménez R, Intriago P (1987) Observations on blooms of Mesodinium rubrum in the upwelling area off Ecuador. Oceanol Acta 6:145-154

Jonsson PR, Tiselius P (1990) Feeding behaviour, prey detection and capture efficiency of the copepod Acartia tonsa feeding on planktonic ciliates. Mar Ecol Prog Ser 60:35-44

Kils U (1993) Formation of micropatches by zooplanktondriven microturbulences. Bull Mar Sci 53:160-169

Kjerfve B (1994) Coastal lagoons. In: Kjerfve B (ed) Coastal lagoons processes. Elsevier, Amsterdam, p 1-8
Knoppers B (1994) Aquatic primary production in coastal lagoons. In: Kjerfve B (ed) Coastal lagoon processes. Elsevier, Amsterdam, p 243-286

Kouassi E, Pagano M, Saint-Jean L, Arfi R, Bouvy M (2001) Vertical migrations and feeding rhythms of Acartia clausi and Pseudodiaptomus hessei (Copepoda: Calanoida) in a tropical lagoon (Ebrié, Côte d'Ivoire). Estuar Coast Shelf Sci 52:715-728

Lankford RR (1977) Coastal lagoons of Mexico, their origin and classification. In: Wiley M (ed) Estuarine processes, Vol II. Circulation, sediments and transfer of material. Academic Press, London, p 182-215

Legendre P (1993) Spatial autocorrelation: trouble or new paradigm? Ecology 74:1659-1673

Legendre P, Legendre L (1998) Numerical ecology. Elsevier, Amsterdam

Lennert-Cody CE, Franks PJS (2002) Fluorescence patches in high-frequency internal waves. Mar Ecol Prog Ser 235: $29-42$

Lindholm T (1985) Mesodinium rubrum-a unique photosynthetic ciliate. Adv Aquat Microbiol 3:1-48

Lindholm T, Mörk AC (1990) Depth maxima of Mesodinium rubrum (Lohmann) Hamburger and Buddenbrockexamples from a stratified Baltic Sea inlet. Sarsia 75:53-64

Lovejoy S, Currie WJS, Tessier Y, Clareboudt MR, Bourget E, Roff JC, Schertzer D (2001) Universal multifractal and ocean patchiness: phytoplankton, physical fields and coastal heterogeneity. J Plankton Res 23:117-141

Mackas D, Denman K, Abbott M (1985) Plankton patchiness: biology in the physical vernacular. Bull Mar Sci 37: $652-674$

Mandelli EF, Vázquez-Botello A (1976) Informe final de la 3a. etapa de estudio sobre el uso de la zona costera en los estados de Michoacán y Guerrero. Centro de Ciencias del Mar y Limnología. Universidad Nacional Autónoma de México, Mexico DF

Margalef R (1956) Structure and dynamics of the red tides of the Ría de Vigo. Invest Pesq 5:113-134

Margalef R (1969) Comunidades planctónicas en lagunas litorales. In: Ayala-Castañares A, Phleger FB (eds) Lagunas costeras, un simposio. UNAM (Universidad Nacional Autónoma de México)-UNESCO, Mexico DF, Nov 28-30, 1967. UNAM, Mexico DF, p 542-562

Margalef R (1975) Ciliados planctónicos de la región de afloramiento del NE de África, según datos de la campaña 'Atlor II'. Result Exped Cient B/O Cornide 4:171-173

Mee L (1978) Coastal lagoons. In: Riley J, Chester R (eds) Chemical oceanography. Academic Press, New York, p 441-490

Mee LD (1977) The chemistry and hydrography of some tropical coastal lagoons, Pacific coast of Mexico. PhD thesis, University of Liverpool

Modigh M (2001) Seasonal variations of photosynthetic ciliates at a Mediterranean coastal site. Aquat Microb Ecol 23(2):163-175

Montagnes D, Lynn D (1989) The annual cycle of Mesodinium rubrum in the waters surrounding the Isles of Shoals, Gulf of Maine. J Plankton Res 11:193-201

Montagnes DJS, Poulton AJ, Shammon TM (1999) Mesoscale, finescale and microscale distribution of micro- and nanoplankton in the Irish Sea, with emphasis on ciliates and their prey. Mar Biol 134:167-179

Montgomery DC (1987) Design and analysis of experiments. John Wiley, New York

Neter J, Wasserman W, Kutner MH (1990) Applied linear statistical models: regression, analysis of variance, and experimental designs. Richard D Irwin, Homewood 
Nielsen TG, Kiørboe T (1991) Effects of a storm on the structure of the pelagic food web with special emphasis on planktonic ciliates. J Plankton Res 13:35-51

Owen RW, Gianesella-Galvao SF, Kutner MBB (1992) Discrete, subsurface layers of the autotrophic ciliate Mesodinium rubrum off Brazil. J Plankton Res 14:97-105

Pace ML, Cole JJ, Carpenter SR (1998) Trophic cascades and compensation: differential responses of microzooplankton in whole-lake experiments. Ecology 79:138-152

Packard TT, Blasco D, Barber RT (1978) Mesodinium rubrum in the Baja California upwelling system. In: Boje R, Tomczak M (eds) Upwelling ecosystems. Springer-Verlag, Berlin, p 73-89

Pagano M, Saint-Jean L (1994) In situ metabolic budget for the calanoid copepod Acartia clausi in a tropical brackishwater lagoon (Ebrié Lagoon, Ivory-Coast). Hydrobiologia 272:147-161

Palomares R, Suárez-Morales E, Hernández-Trujillo S (1998) Catálogo de los copépodos (Crustacea) pelágicos del Pacífico Mexicano. CICIMAR-IPN, México

Pannatier Y (1996) Variowin: software for spatial data analysis in 2D. Springer-Verlag, New York

Parsons T, Takahashi M, Hargrave B (1977) Biological oceanographic processes. Pergamon Press, Oxford

Pearce SC (1982) Analysis of covariance. In: Kotz S, Johnson NL (eds) Encyclopaedia of statistics. John Wiley, New York, p 61-69

Pinel-Alloul B, Guay C, Angeli N, Legendre P, Dutilleul P, Balvay G, Gerdeaux D, Guillard J (1999) Large-scale spatial heterogeneity of macrozooplankton in Lake of Geneva. Can J Fish Aquat Sci 56:1437-1451

Platt T, Denman K (1980) Patchiness in phytoplankton distribution. In: Morris I (ed) The physiological ecology of phytoplankton. Blackwell, Oxford, p 413-431

Powell TM, Okubo A (1994) Turbulence, diffusion and patchiness in the sea. Phil Trans R Soc Lond B 343:11-18

Powell T, Richerson P, Dillon T, Agee B, Dozier B, Godden D, Myrup L (1975) Spatial scales of current speed and phytoplankton biomass fluctuations in Lake Tahoe. Science 189: 1088-1090

Ripley BD (1992) Stochastic models for the distribution of rock types in petroleum reservoirs. In: Walden AT, Guttorp P (eds) Statistics in the environmental and earth sciences. Halsted Press, New York, p 247-282

Roa R, Tapia F (2000) Cohorts in space: geostatistical mapping of the age structure of the squat lobster Pleuroncodes monodon population off central Chile. Mar Ecol Prog Ser 196:239-251

Rossi RE, Mulla DJ, Journel AG, Franz EH (1992) Geostatisti-

Editorial responsibility: John Dolan (Contributing Editor),

Villefranche-sur-Mer, France cal tools for modeling and interpreting ecological spatial dependence. Ecol Monogr 62:277-314

Seuront L, Gentilhomme V, Lagadeuc Y (2002) Small-scale nutrient patches in tidally mixed coastal waters. Mar Ecol Prog Ser 232:29-44

Seuront L, Schmitt F, Lagadeuc Y, Schertzer D, Lovejoy S, Frontier S (1996) Multifractal analysis of phytoplankton biomass and temperature in the ocean. Geophys Res Lett 23:3591-3594

Sorokin YI, Sorokin PY, Ravagnan G (1999) Analysis of lagoonal ecosystems in the Po River delta associated with intensive aquaculture. Estuar Coast Shelf Sci 48:325-341

Sorokin YI, Sorokin PY, Zakouskina OY (2003) Microplankton and its function in a zone of shallow hydrothermal activity: the Craternaya Bay, Kurile Islands. J Plankton Res 25: 495-506

Soto-Castor R, Bulit C, Esquivel-Herrera A, Pérez-Rojas A (2002) Bacterial abundance and hydrological variation in a tropical lagoon during the rainy season. Oceánides 17(1): $13-29$

Steele JH (1978) Some comments on plankton patches. In: Steele JH (ed) Spatial pattern in plankton communities. Plenum Press, New York, p 1-20

Steele JH, Henderson EW (1992) A simple model for plankton patchiness. J Plankton Res 14:1397-1403

Stoecker DK, Taniguchi A, Michaels AE (1989) Abundance of autotrophic, mixotrophic and heterotrophic planktonic ciliates in shelf and slope waters. Mar Ecol Prog Ser 50: 241-254

Stoecker DK, Putt M, Davis LH, Michaels AE (1991) Photosynthesis in Mesodinium rubrum: species-specific measurements and comparison to community rates. Mar Ecol Prog Ser 73:245-252

Taylor WD, Berger J (1980) Microspatial heterogeneity in the distribution of ciliates in a small pond. Microb Ecol 6:27-34

Vaqué D, Blough HA, Duarte CM (1997) Dynamics of ciliate abundance, biomass and community composition in an oligotrophic coastal environment (NW Mediterranean). Aquat Microb Ecol 12:71-83

Waters RL, Mitchell JG, Seymour J (2003) Geostatistical characterisation of centimetre-scale spatial structure of in vivo fluorescence. Mar Ecol Prog Ser 251:49-58

Wilkerson FP, Grunseich G (1990) Formation of blooms by the symbiotic ciliate Mesodinium rubrum: the significance of nitrogen uptake. J Plankton Res 12(5):973-989

Yáñez-Arancibia A (1978) Ecological patterns and cyclical variations of the trophic structure in nektonic communities in coastal lagoons on the Pacific coast of Mexico. An Cent Cienc Mar Limnol 5:287-305

Submitted: July 7, 2003; Accepted: December 2, 2003

Proofs received from author(s): March 1, 2004 